\title{
Mezinárodní konference o církvi
}

P R O K P B R O Ž

Ve dnech 10. a 11. ř́jna 2012 se na Katolické teologické fakultě Univerzity Karlovy v Praze konala mezinárodní konference Církev a II. vatikánský koncil: Ekleziologie - její statut a perspektiva. Pohnutka, proč konferenci pořádat, vycházela s faktu, že se dnes o církvi ve veřejném prostoru sice hovoří dost, nicméně popisy nebo hodnocení jsou jí implantovány zvnějšku. Je dobré se zastavit a zjistit, jak církev nahlíží sebe samu ve svých vlastních východiscích. Konference chtěla zaměřit pozornost na sebepojetí církve $\mathrm{v}$ teologické perspektivě.

Dvoudenní konference byla rozdělena na čtyři části. V první části, věnované tématu církev a svět, G. Canobbio, italský teolog z Brescie, představil církev v její zásadně extrovertní charakteristice. Církev je úzce spojena se světem, do něhož je poslána. Na něj navazoval R. Repole, teolog z Turína, který rozvinul téma pokory církve. V době postmoderního myšlení, které se vykazuje vysokou mírou plurality, jíž hrozí kolážovitost a relativismus, se církev nemůže vydat všanc tzv. slabému myšlení (il pensiero debole), nýbrž myšlení pokornému. Chce-li církev působit ve světě, musí být vsazena do rámce Božího království. P. Brož ukázal, jaké rysy církev získá, když svou existenci chápe jako službu Božímu království. Církev je totiž „zárodek a počátek tohoto království na zemi“ (LG 5). Také ukázal, jak je třeba chápat hierarchickou dimenzi církve: jako institucionálně strukturované společenství (communio) univerzální církve.

Druhá část konference patřila tématu „církev a spása“. Vídeňský teolog J.-H. Tück otevřel téma přednáškou s klasickou tezí „mimo církev není spásy“ a ukázal její význam v perspektivě jejího vývoje. J. Brož představil téma spásy v listu Židům. Spása je zde v úzkém sepětí s kněžstvím Ježíše Krista, jež je podstatně spojené s dějinami světa. V době pozdní antiky si církev byla vědoma toho, že její osud je spojený s osudem světa, a proto naslouchala tehdejším představám, náboženským představám, o spáse. D. Červenková na postavě Tertuliána ukázala, jak církev v té době uměla být otevřená. Je-li církev spojena se spásou světa, nemůžeme obejít její základní eschatologický ráz. V. Novotný auditoriu představil nejprve genezi 7. kapitoly dogmatické konstituce o církvi Lumen gentium, která pojednává o eschatologickém 
rysu putující církve. Posléze formuloval teologické základy definitivní platnosti církve pro spásu světa: je to její sepětí s Kristem, Božím Synem, který své spásné dílo působí v jednotě celé Nejsvětější Trojice.

Třetí část konference se nesla v duchu „teologických sond“. Ukázalo se jako užitečné vybrat z širokého spektra teologických oborů několik témat, která se identity církve dotýkají. B. Mohelník ukázal, jak je církev nahlížena ve světle sakramentální teologie. D. Bouma v perspektivě fundamentální teologie představil široce založený projekt španělského teologa Salvadora Pié-Ninota. Prof. P. Ambros na pozadí východní tradice a současných pravoslavných autorů představil tzv. eucharistickou ekleziologii a její konstitutivní prvky. Vedle východní tradice byla prof. P. Filipim účastníkům konference představena též česká reformační tradice a její pojetí církve. Důležitým místem, kde se dnes o povaze církev rozhoduje, je liturgie. R. Tichý proto předvedl obraz církve, která v liturgii vyjevuje svoji identitu.

Poslední část sledovala církev, která má své zásadně dějinné určení. Př́spěvek J. Juháse byl nadepsán „Církev v mezičase“ a v intencích teologie H. Künga a L. Boffa ukázal, jak církev bojuje mezi sebeabsolutizací a seberelativizací. Veronský teolog G. Laiti na životě církve po II. vatikánském koncilu ukázal, jak důležité je pojmout reformu církve v jejím vývoji, nikoliv jen v tezích či principech. V. Ventura načrtl několik přístupů k církvi tak, jak se v průběhu pokoncilního Československa utvářely.

Konference nakonec představila teologicky pravdivou, lidsky pokornou a účinnou církev. Veškeré obtíže, potíže i složitosti v církvi je nutné nahlížet nejen v rámci vývoje života církve, ale také ve světle Boží prozřetelnosti. 